\title{
FECUNDITY AND FERTILITY OF Macrobrachium amazonicum (CRUSTACEA, PALAEMONIDAE)
}

\author{
DA SILVA, R. R., SAMPAIO, C. M. S. and SANTOS, J. A. \\ Laboratório de Ciências Biológicas, Centro de Ciências da Saúde, Universidade Estadual do Ceará, \\ Av. Paranjana, 1700, CEP 60740-093, Fortaleza, Ceará, Brazil \\ Correspondence to: Célia Maria de Souza Sampaio, Laboratório de Ciências Biológicas, Centro de Ciências da \\ Saúde, Universidade Estadual do Ceará, Av. Paranjana, 1700, CEP 60740-093, \\ Fortaleza, Ceará, Brazil, e-mail: cmsamp@uece.br \\ Received March 18, 2003 - Accepted September 11, 2003 - Distributed August 31, 2004
}

(With 6 figures)

\begin{abstract}
In Brazil, studies with native freshwater prawn species were discontinued due to great importance of Macrobrachium rosenbergii. Therefore, it is necessary to continue investigations about our species, in order to develop technology adequate to our reality and in a future allow prawn farmers to culture other species. The aim of this study was to determine the fecundity and fertility of Macrobrachium amazonicum captured monthly from June 1999 to June 2001 from Jaguaribe River, Itaiçaba, Ceará, Brazil. Prawns were collected using fishing net and transferred at Biological Science Laboratory, Ceará State University (Fortaleza, Ceará, Brazil). Among the ovigerous M. amazonicum females, 60 were randomly selected to determine fecundity. The eggs adhered to the pleopods were taken out and they were then placed in a Gilson solution, and then stored in alcohol $70 \%$. Individual fecundity was determined from the total egg counting, using a stereoscopic microscope. To determine fertility, ovigerous $M$. amazonicum females were stored in individual $10 \mathrm{~L}$-glass tanks maintained under strong aeration. After the hatching, the larvae were siphoned and counted. The data referring to total length and weight of all the females, storage date, coloration and number of eggs, weight and coloration of gonad and number of hatched larvae were noted. With respect to average fecundity $(\mathrm{F})$ by length classes, the lowest and highest number of eggs observed was 696 and 1,554, respectively. As for fecundity by weight classes, the lowest number of eggs observed was 760 and the highest, 1,690. The highest number of eggs observed individually per hatching was 2,193. Average fecundity/total length (L) and average fecundity/total weight (W) may be expressed by a linear relationship. The adjusted equations are: $\mathrm{F}=-411.6+203.1 \mathrm{~L}(\mathrm{p}<0.0001)$ and $\mathrm{F}=566.4+$ $157.3 \mathrm{~W}(\mathrm{p}<0.0001)$, respectively. In the analysis of average fertility $(\mathrm{N})$ per length classes, the lowest and highest number of larvae observed was 374 and 1,301, respectively. With respect to fertility per weight classes, the lowest number of larvae was 581 and the highest, 1,391. In this work, the maximum number of larvae observed per hatching for females kept in laboratory was 2,594. Average fertility/total length and average fertility/total weight may be expressed by a linear relationship. The adjusted equations are: $\mathrm{N}=-1042.7+264.9 \mathrm{~L}(\mathrm{p}<0.0002) ; \mathrm{N}=384.1+160.3 \mathrm{~W}(\mathrm{p}<0.003)$. From these results we can deduced that fecundity and fertility of M. amazonicum are lower than ones commercial species, nevertheless it can be captured during all year long. The number of captured prawns was large in the months whose level of water was low; the inverse was observed in the months that the river was with a high volume of water.
\end{abstract}

Key words: fertility, fecundity, Macrobrachium amazonicum.

\section{RESUMO}

\section{Fecundidade e fertilidade de Macrobrachium amazonicum (Crustacea, Palaemonidae)}

No Brasil, os estudos com espécies nativas de camarões de água doce foram interrompidos em decorrência da importação de Macrobrachium rosenbergii. Entretanto, é necessário continuar as investigações com 
nossas espécies, com o objetivo de desenvolver tecnologia adequada à nossa realidade e, em um futuro próximo, de permitir aos carcinicultores outras opções para cultivo. O objetivo deste estudo foi determinar a fecundidade e a fertilidade de Macrobrachium amazonicum, capturado mensalmente de junho de 1999 a junho de 2001, no Rio Jaguaribe, em Itaiçaba, Ceará, Brasil. Após a coleta, os camarões foram transportados para o Laboratório de Ciências Biológicas, na Universidade Estadual do Ceará (Fortaleza, Ceará, Brasil). Foram selecionadas, aleatoriamente, 60 fêmeas ovígeras para a determinação da fecundidade. Os ovos aderidos aos pleópodes foram retirados, colocados em Solução de Gilson e estocados em álcool 70\%. A fecundidade individual foi determinada a partir da contagem total dos ovos de cada fêmea. Para determinar a fertilidade, fêmeas ovígeras de $M$. amazonicum foram estocadas individualmente em aquários de vidro de $10 \mathrm{~L}$. Após a eclosão, as larvas foram sifonadas e contadas. Os dados referentes ao comprimento e peso total de todas as fêmeas, à data de estocagem, à coloração e número de ovos, ao peso e coloração das gônadas e ao número de larvas eclodidas foram registrados. O menor e o maior número de ovos observados por classes de comprimento foram de 696 e 1.554, respectivamente. Para a fecundidade por classes de peso, o menor número de ovos observados foi de 760 e o maior, de 1.690 . O número mais elevado de ovos observados individualmente por desova foi 2.193 . Fecundidade média/ comprimento total (L) e fecundidade média/peso total (W) podem ser expressas por relação linear. As equações ajustadas são $\mathrm{F}=-411,6+203,1 \mathrm{~L}(\mathrm{p}<0,0001)$ and $\mathrm{F}=566,4+157,3 \mathrm{~W}(\mathrm{p}<0,0001)$, respectivamente. $\mathrm{Na}$ análise da fertilidade $(\mathrm{N})$ por classes de comprimento, o menor e o maior número de larvas observados foram 374 e 1.301, respectivamente. Quanto à fertilidade por classes de peso, o menor número de larvas foi de 401 e o maior, de 1.231. Neste trabalho, o número máximo de larvas observado por desova para fêmeas mantidas em laboratório foi de 2.594. Fertilidade média/comprimento total e fertilidade média/peso total podem ser expressos por relação linear. As equações ajustadas são: $\mathrm{N}=-1042,7+264,9$ $\mathrm{L}(\mathrm{p}<0,0002) ; \mathrm{N}=384,1+160,3 \mathrm{~W}$ ( $\mathrm{p}<0,003$ ). A partir desses resultados, podemos deduzir que $M$. amazonicum apresenta menor fecundidade e fertilidade que outras espécies comercializadas, podendo ser capturado durante todo o ano. O número de camarões foi variável, a maior quantidade foi observada nos meses em que o rio apresentou menor nível, e vice-versa.

Palavras-chave: fecundidade, fertilidade, Macrobrachium amazonicum.

\section{INTRODUCTION}

The freshwater prawn farming has already become in the last years a major contributor to global aquaculture, in terms of quantity and value (New, 2000).

Historically the freshwater prawns production was $5 \%$ of the whole prawn production in the world (New, 1995). However according to FAO data (2000), cited by Valenti (2002), world production of freshwater prawn between 1990 and 2000 increased from 21,000 to 118,500 tons per year, which corresponds to an increase of about $500 \%$. Although these data refers only to Macrobrachium rosenbergii, the most cultivated species in the world, another two species are becoming increasingly more popular in some Asian countries, M. malcolmsonii in India and $M$. nipponense in China (Kutty et al., 2000).

An special prawn species is considered economically feasible for farming when it presents some characteristics such as fast growth rate, easy repro- duction in captivity, high fecundity, rusticity, low aggressiveness, resistance to diseases and commercial value (Coelho et al., 1981; Valenti, 1985).

The freshwater prawn farming is simpler than saltwater prawn, with lower costs, since the ponds may be built in small, medium and large size properties, located on the coast or inland (Amaral \& Neves, 1989; Valenti, 1990).

Freshwater prawns are decapode crustaceans belonging to the Palaemonidae family. Although they are also called prawns as their saltwater counterparts, they are closer to lobster regarding their evolution, thus presenting many similarities mainly with respect to reproduction habits (Jalihal et al., 1993; Valenti, 1996; Pinheiro \& Hebling, 1998; Ismael \& New, 2000). The vast majority of freshwater prawn species of commercial interest belong to the Macrobrachium genus is founded in the tropical and subtropical regions of the world (Bowman \& Abele, 1982; Chace, 1992).

In Brazil, studies with the three most important indigenous freshwater prawn species M. acanthurus, 
M. amazonicum and $M$. carcinus started in the beginning of the 70s, with the objective of developing a farming technology adequate to our reality (Cavalcanti, 1998). However, these investigations were discontinued in 1977 due to import of $M$. rosenbergii post-larvae, an exotic species with welldeveloped farming techniques throughout the world (Valenti, 1993). Currently, M. rosenbergii is the only freshwater prawn species used in commercial farming, since their biology and farming technology are well known compared to other species (Valenti, 1990). Therefore, it is necessary to continue investigations about occurrence, life cycle, reproduction, growth and habitat of our native species, in order to develop technology adequate to our reality, and in a near future allow prawn farmers to cultivate other species.

From the Brazilian indigenous species, $M$. amazonicum is currently preferred for farming, due to fast growth and easy maintenance in captivity. Although total growth is less than for M. acanthurus and $M$. carcinus, the species does not present the aggressiveness characteristic of those, in addition to being more resistant to diseases and predators (Lobão \& Rojas, 1991).

M. amazonicum is indigenous in South America, and can be found in several rivers of the continent from Venezuela to Paraguay (Rodriguez, 1980; Romero, 1980; Gamba, 1984). In Brazil, the species can be found in rivers and lakes of the North, Northeast and Midwest, which indicates the species has preference for hot climate regions (Kensley \& Walker, 1982; Bialetzki et al., 1997).

The researches about $M$. amazonicum have been developed in the last years with the involvement of universities, institution of research and agencies of development. In Pará, Brazil, M. amazonicum postlarvae of that species are produced in commercial pounds (Moraes-Riodades \& Valenti, 2001).

M. amazonicum was brought from the Amazon basin in the 40s and introduced by the Fishery Service from the Departamento Nacional de Obras Contra as Secas (DNOCS) in several dams of the Northeast as forager species for carnivore fishes (Paiva \& Campos, 1995). Due to adaptation and facility to reproduce in confinement, the species disseminated throughout the rivers and lakes of the region, thus becoming an important food source and reaching wide commercialization in the Northeast (Valenti, 1985).

According to Lombardi et al. (1996), in Brazil, population of river banks has subsisted on freshwater prawn fishing either as food or bait used for fishing. The majority of prawns used in such activities belong to Macrobrachium genus. Still, according to these authors, there are several research institutions that investigate indigenous species to elaborate farming techniques that in addition to commercial ends also help to replace natural stocks.

Most of the work done in Brazil with $M$. amazonicum discuss aspects related to biology and farming techniques of fishing collected mainly in the Amazon and Northeast regions; among them the works of Pinto (1977); Coelho et al. (1982a, b); Silva et al. (1982); Vega-Perez (1984); Magalhães (1985); Alves (1986); Lobão et al. (1986); Moreira \& McNamara (1986); Odinetz Collart (1987); Magalhães (1988); Magalhães \& Walker (1988); Scaico \& Bragagnoli (1989); Odinetz Collart (1991a, b); Scaico (1992); Odinetz Collart \& Magalhães (1994); Odinetz Collart \& Rabelo (1996) and Porto (1998). There are also the works of Guest (1979) and Guest \& Durocher (1979) conducted in the US with species originated from Lima Campos Dam, Ceará, Brazil to determine life cycle and species tolerance to low salinity and temperature aiming at introducing the species to Texas reservoirs. Among these works, only Scaico (1992) determined fecundity and fertility of M. amazonicum females of a lake located in Paraiba, Brazil.

According to Vazzoler (1982); Lobão et al . (1985) and Valenti et al. (1989) the knowledge of species fecundity is important to evaluate its potential for commercial farming, as well as an estimation of reproductive potential and the stock size of natural population. In addition, it can also be utilized to determine the minimum number of adults necessary to maintain the recruitment and egg survival rates until adulthood.

Santos (1978) defined fecundity as the number of eggs laid by one female per hatching. However, Bond \& Buckup (1982) defined fecundity as the number of eggs laid per hatching that was found to adhere to the female pleopods, definition to be used in the present work.

Lobão et al. (1986) observed that not all eggs incubated by one female are viable, and sometimes the number of hatched larvae may be inferior to the number of eggs produced. For this reason, it is important to evaluate female fertility, that is, the number of larvae produced in the same hatching.

Due to lack of work about reproductive biology of M. amazonicum in Ceará state, this work aimed 
at determining fecundity and fertility of this species and their relationship with animal length and weight.

\section{MATERIAL AND METHODS}

\section{Sampling period and local}

M. amazonicum were captured monthly from June 1999 to June 2001, from Jaguaribe River, Itaiçaba, Ceará, located above Work Channel dam, at $200 \mathrm{~m}$ altitude and $04^{\circ} 40^{\prime} 28^{\prime \prime} \mathrm{S}$ and $37^{\circ} 49^{\prime} 21^{\prime \prime} \mathrm{W}$.

Jaguaribe River is $633 \mathrm{~km}$ long and is divided into three sub-basins: High, Medium and Low Jaguaribe, this is $137 \mathrm{~km}$ long and flows into the Atlantic at Aracati town. Contrary to the other two, this sub-basin is characterized by predominance of sedimentary soil compared to crystalline (Atlas do Ceará, 1995).

\section{Sampling material}

Prawns were collected by a fisherman using fishing net and transferred to Biological Science Laboratory, at Universidade Estadual do Ceará (LABIO/UECE).

In laboratory, live prawns were placed in 500 L-tanks, equipped with biological filter and plenty aeration. Daily, at the end of the afternoon, individuals were fed artificial ration for aquatic organisms at a ratio of $10 \%$ of the biomass of each tank.

The dead prawns were examined and identified using a stereoscopic microscope. Macrobrachium species were identified according to classification proposed by Gomes-Corrêa (1977), Holthuis (1952, 1980), Rodriguez (1980) and Williams (1984).

\section{Fecundity determination}

Among the ovigerous females collected monthly, 60 were randomly selected to determine fecundity.

Using a caliper rule with $0.05 \mathrm{~mm}$ precision, it was determined: abdomen length (Lc) defined as the distance between distal extremity of rostrum and the medium point of posterior part of carapace; the length of abdomen + telson $(\mathrm{La}+\mathrm{t})$ defined as the distance between the medium point of supero-anterior edge of the first abdominal segment and the distal extremity of telson. Total length (Lt) was defined as $\mathrm{Lc}+\mathrm{La}+\mathrm{t}$. Also, for each individual, total weight (Wt) was determined using a $0.1 \mathrm{~g}$ precision scale.

From each female, the eggs adhered to the pleopods were taken out using tweezers and scissors. Eggs were then placed in a plastic container filled with Gilson solution to ease the dissociation and stored in alcohol $70 \%$.

Individual fecundity was determined from the total egg counting, using a stereoscopic microscope $(10 \mathrm{X})$ with the help of a plastic camera to facilitate visualization and counting. The data referring to length of cephalothoraxes, abdomen, total length and weight of the females, coloration and number of eggs, weight and coloration of gonad were noted in an appropriate form.

To determine average fecundity, females with eggs were grouped in length $(\mathrm{cm})$ and weight $(\mathrm{g})$ classes.

\section{Fertility determination}

To determine fertility, M. amazonicum ovigerous females with eggs were transferred alive from the sampling place to Biological Science Laboratory and stored in $500 \mathrm{~L}$-fiberglass boxes equipped with biological filter and plenty aeration. Daily, prawns were fed commercial ration at ratio of $10 \%$ of the biomass contained in each box.

Later on, females with eggs were transferred from the boxes to individual $10 \mathrm{~L}$-glass-fish tanks maintained under strong aeration. Females were fed daily with fish and artificial ration for aquatic organisms. Waste ration and feces were siphoned daily and the water replaced. In addition, the general condition of the females was observed to notice the occurrence of hatching.

When hatching occurred, the larvae were attracted to the sidewall of the aquarium using directed light, since they present positive phototactism. After that, they were siphoned to a container filled with water to count the number of hatched larvae by transferring them with the help of a pipette to a second recipient. For each female that hatched, length and weight data were determined for fecundity analysis.

In a identical procedure used for fecundity analysis, data related to length of cephalothoraxes, abdomen + telson total length and weight of the female, storage date, egg color, hatching date, gonad color and number of hatched larvae were also noted in appropriate form.

From the individual data for fecundity and fertility, it was determined average fecundity and fertility for M. amazonicum females by weight and length classes. The analyzed individuals were grouped in $0.5 \mathrm{~cm}$ length and $0.5 \mathrm{~g}$ weight classes. After that, the relationship between average fecundity - length 
and weight, as well as average fertility - length and weight were also determined.

\section{RESULTS}

\section{Influence of rain on the sampling collection}

In spite of M. amazonicum females have been caught every month, the amount of prawns captured from June 1999 to June 2001 was not constant during this period. During the months of April and December 2000 and in March 2001, when the river was strongly affected by the heavy rains in the region, a total absence of individuals was observed. Apparently, this fact may be related with increasing water level due to rainfall. When the level of the river was lower, fishing was more abundant and the opposite was observed when the level was higher and consequently, the current stronger.

\section{Average fecundity determination}

Average fecundity (F) of M. amazonicum females, originated from Low Jaguaribe collected between July 1999 and June 2001, by length and weight classes can be seen in Tables 1 and 2, respectively.

For all observed length and weight classes, average fecundity was always higher than average fertility (Figs. 1 and 2).

With respect to average fecundity by length classes, the highest and lowest number of eggs observed was 1,554 and 480 , respectively. As for fecundity by weight classes, the lowest number of eggs observed was 619 and the highest, 2,128 (Tables 1 and 2).

Average fecundity/total length and average fecundity/total weight may be expressed by a linear relationship represented in Figs. 3 and 4, respectively. The adjusted equations are:

$$
\begin{aligned}
& \mathrm{F}=-411.6+203.1 \mathrm{~L}(\mathrm{p}<0.0001) \\
& \mathrm{F}=566.4+157.3 \mathrm{~W}(\mathrm{p}<0.0001)
\end{aligned}
$$

where $\mathrm{F}=$ average fecundity; $\mathrm{L}=$ total length $(\mathrm{cm})$; and $\mathrm{W}=$ total weight $(\mathrm{g})$.

\section{Average fertility determination}

Average fertility $(\mathrm{N})$ of $M$. amazonicum females, originated from Low Jaguaribe collected between June 1999 and June 2001, by length and weight classes can be seen in Tables 1 and 2, respectively.

In the analysis of average fertility per length classes, the lowest and highest number of larvae observed was 397 and 1,301, respectively. With respect to fertility per weight classes, the lowest number of larvae was 401 and the highest, 1,915 (Tables 1 and 2).

Average fertility/total length and average fertility/total weight may be expressed by a linear relationship represented in Figs. 5 and 6, respectively. The adjusted equations are:

$$
\begin{gathered}
\mathrm{N}=-1042.7+264.9 \mathrm{~L}(\mathrm{p}<0.0002) \\
\mathrm{N}=384.1+160.3 \mathrm{~W}(\mathrm{p}<0.003)
\end{gathered}
$$

where $\mathrm{N}=$ average fertility; $\mathrm{L}=$ total length $(\mathrm{cm})$; and $\mathrm{W}=$ total weight $(\mathrm{g})$.

\section{DISCUSSION AND CONCLUSION}

The fecundity of Macrobrachium prawns is very variable. The hightest fecundity in species of this genus is observed in $M$. rosenbergii and $M$. carcinus, which females can lay between 80,000 and 100,000 eggs in each spawning when they are fully mature. In the first spawning they can be lay not more than 5,000 and 20,000 eggs (Ismael \& New, 2000). Valenti et al. (1986, 1989) observed M. acanthurus females hatched about 18,000 egg, while Shokita, cited by Scaico (1992) observed females with 13,600. Although M. amazonicum captured in Lower Jaguaribe presents a smaller fecundity than those species, it presents higher fecundity than $M$. shokitai, whose fecundity is lower than 60 eggs, and M. jelski, M. iheringi, M. borelli, M. potiuna, and M. australiense, whose absolute fecundity is lower than 200 eggs (Shokita, cited by Scaico, 1992).

In our study, the highest number of eggs observed individually per hatching of $M$. amazonicum was 2,193. This result was below the 6,000 eggs per hatching reported by Coelho et al. (1982b) for $M$. amazonicum. However, the results reported in this work are higher than the values reported by Romero (1980) and Gamba (1984), who reported 953 and 1,000, respectively. Lobão et al. (1986) reported 1,344 eggs per hatching for females hatched in laboratory originating from Belém, Pará, and Porto (1998) reported a average fecundity of only 114 eggs.

According to Magalhães (1985), contrary to larger species, M. amazonicum may have their entire life cycle restricted to freshwater and present monthly hatchings. According to Romero, cited by Magalhães (1985) and Lobão et al. (1986) monthly hatchings may compensate for the lower fecundity, thus making commercial culture feasible. 
TABLE 1

Average fecundidade (F) and fertility (N) by length classes for Macrobrachium amazonicum.

\begin{tabular}{|c|c|c|c|c|}
\hline $\begin{array}{c}\text { Length classes } \\
(\mathbf{c m})\end{array}$ & $\begin{array}{c}\text { Average fecundity } \\
(\mathbf{F})\end{array}$ & $\begin{array}{c}\text { Number of } \\
\text { individuals }\end{array}$ & Average fertility (N) & $\begin{array}{c}\text { Number of } \\
\text { individuals }\end{array}$ \\
\hline $5.0 \square 5.5$ & 696 & 14 & - & - \\
\hline $5.5 \square 6.0$ & 695 & 53 & 374 & 05 \\
\hline $6.0 \square 6.5$ & 773 & 123 & 585 & 58 \\
\hline $6.5 \square 7.0$ & 994 & 218 & 925 & 50 \\
\hline $7.0 \square 7.5$ & 1,139 & 287 & 1,044 & 32 \\
\hline $7.5 \square 8.0$ & 1,183 & 178 & 1,284 & 20 \\
\hline $8.0 \square 8.5$ & 1,287 & 130 & 1,301 & 12 \\
\hline $8.5 \square 9.0$ & 1,377 & 47 & 1,231 & - \\
\hline $9.0 \square 9.5$ & 1,423 & 10 & - & 236 \\
\hline $9.5 \square 10.0$ & 1,554 & 06 & & 32 \\
\hline Total & & 1,066 & & \\
\hline
\end{tabular}

TABLE 2

Average fecundity (F) and fertility (N) by weight classes for Macrobrachium amazonicum.

\begin{tabular}{|c|c|c|c|c|}
\hline Weight classes $(\mathbf{g})$ & $\begin{array}{c}\text { Average fecundity } \\
\mathbf{( F )}\end{array}$ & $\begin{array}{c}\text { Number of } \\
\text { individuals }\end{array}$ & Average fertility (N) & $\begin{array}{c}\text { Number of } \\
\text { individuals }\end{array}$ \\
\hline $1.5 \square 2.0$ & 760 & 99 & 581 & 19 \\
\hline $2.0 \square 2.5$ & 840 & 182 & 756 & 47 \\
\hline $2.5 \square 3.0$ & 1,089 & 204 & 805 & 30 \\
\hline $3.0 \square 3.5$ & 1,183 & 202 & 1,027 & 18 \\
\hline $3.5 \square 4.0$ & 1,185 & 131 & 1,136 & 29 \\
\hline $4.0 \square 4.5$ & 1,270 & 92 & 1,391 & 06 \\
\hline $4.5 \square 5.0$ & 1,414 & 42 & 1,180 & 09 \\
\hline $5.0 \square 5.5$ & 1,277 & 36 & 1,145 & - \\
\hline $5.5 \square 6.0$ & 1,293 & 24 & - & - \\
\hline $6.0 \square 6.5$ & 1,583 & 07 & - & 226 \\
\hline $6.5 \square 7.0$ & 1,690 & 08 & & \\
\hline Total & & 1,027 & & \\
\hline
\end{tabular}




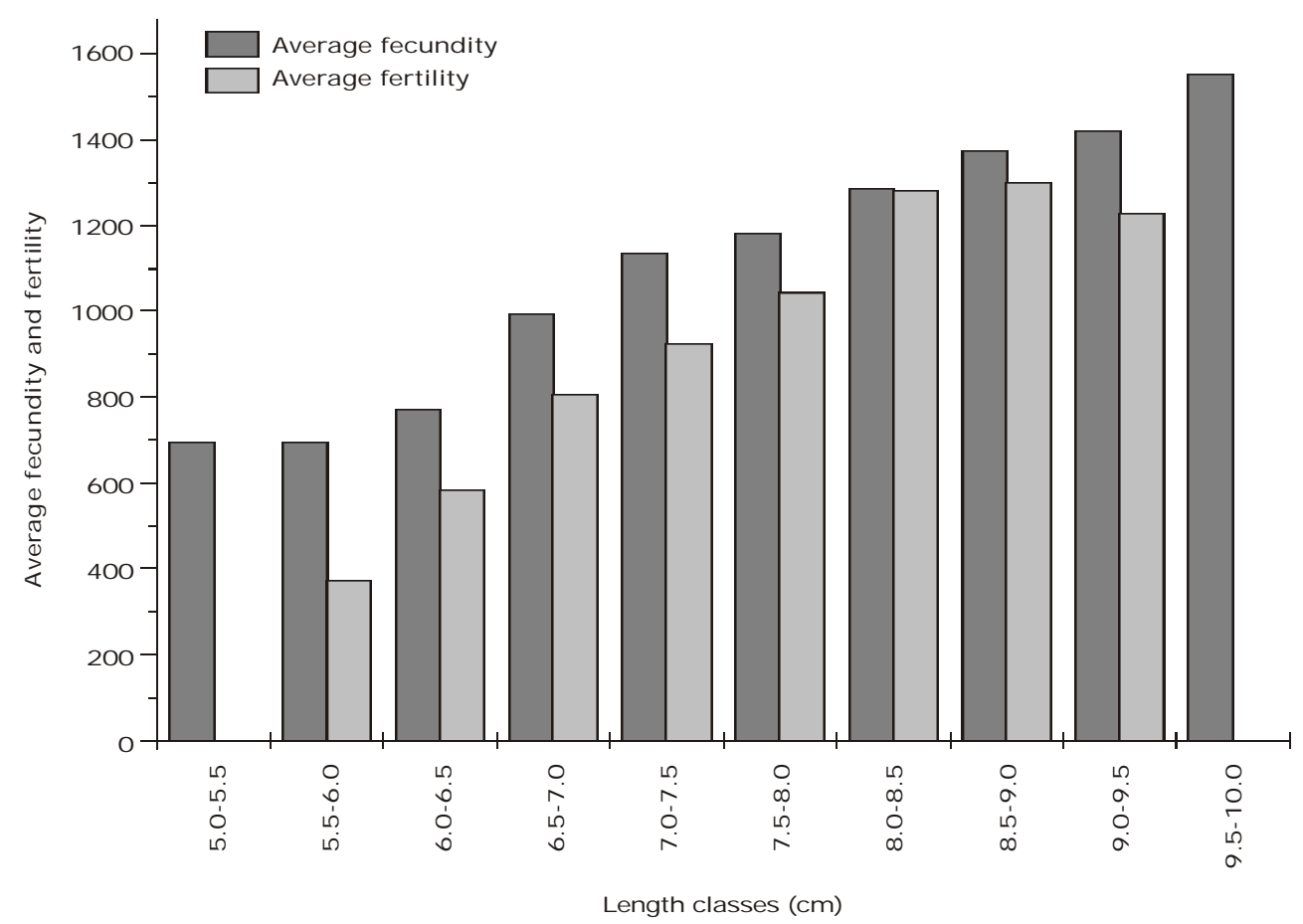

Fig. 1 - Average fecundity and fertility by length classes for M. amazonicum.

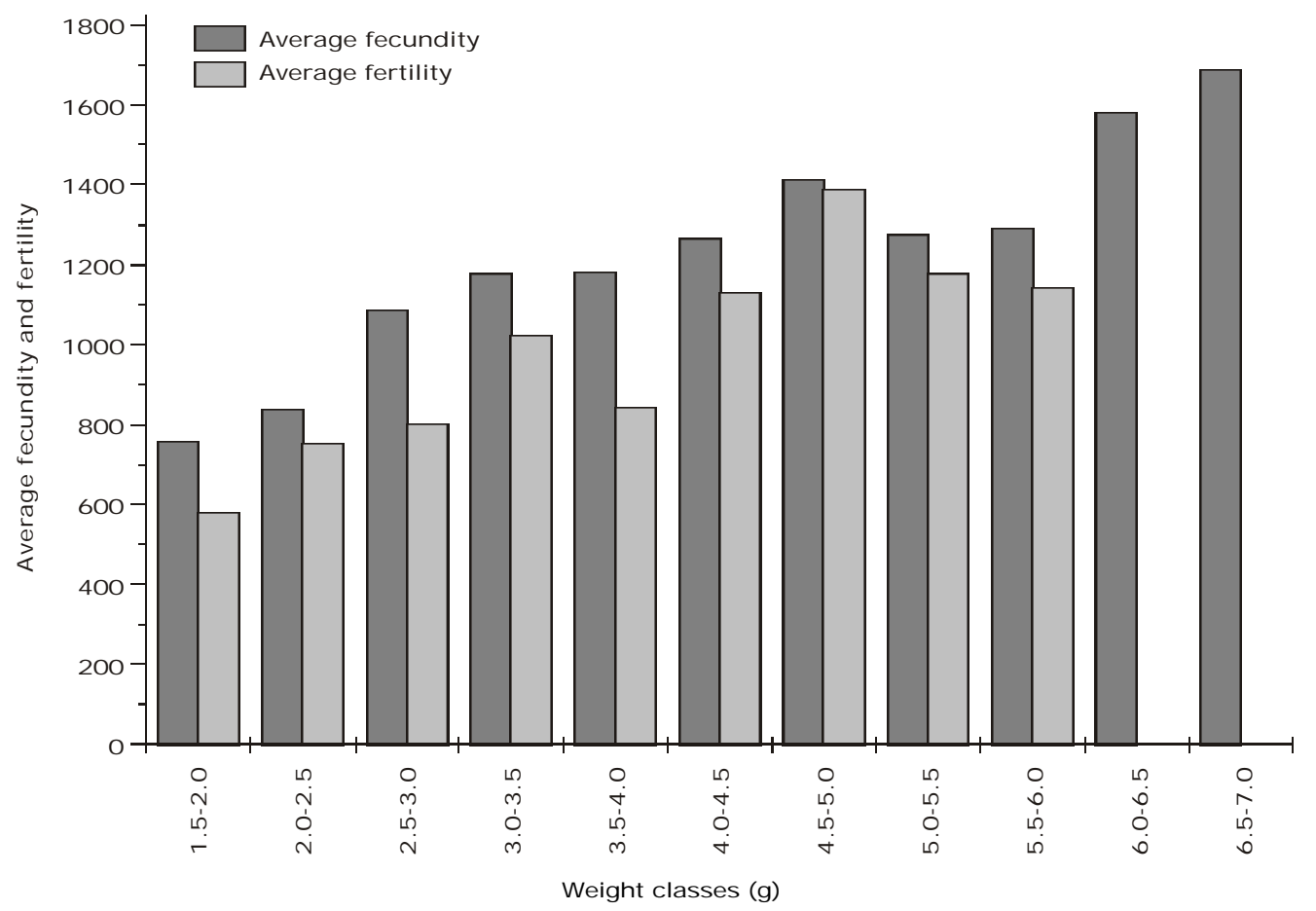

Fig. 2 - Average fecundity and fertility by weight classes for M. amazonicum. 


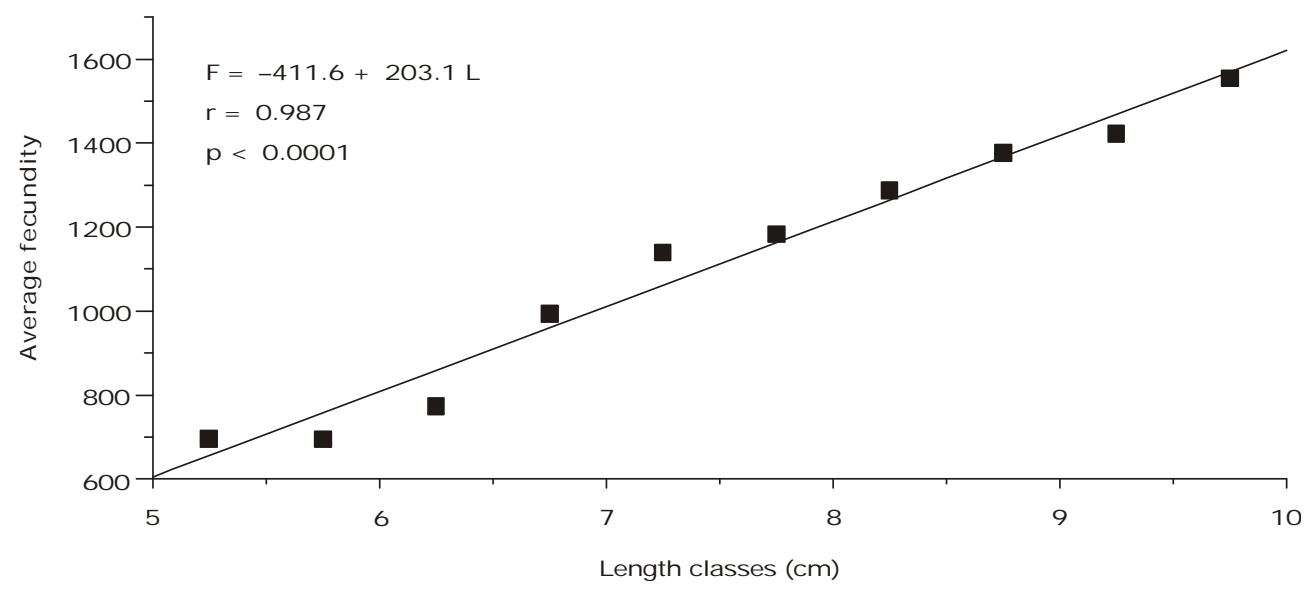

Fig. 3 - Relationship between average fecundity (F) and classes length (L) for M. amazonicum females.

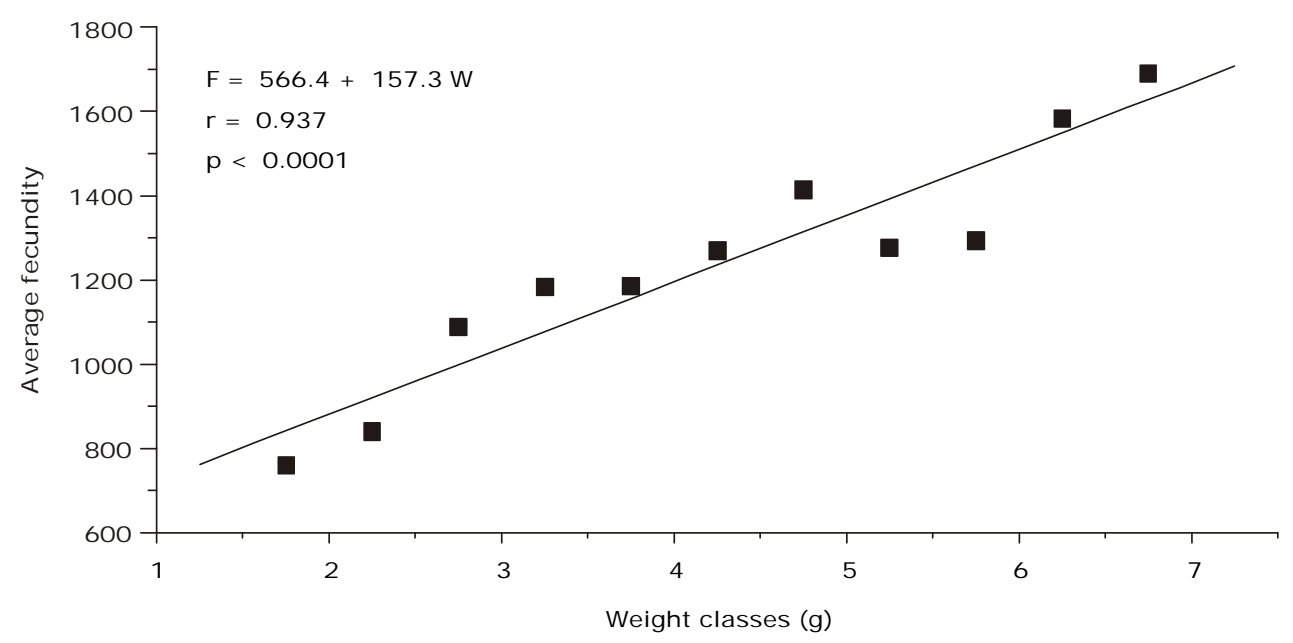

Fig. 4 - Relationship between average fecundity (F) and classes weight (W) for M. amazonicum females. 


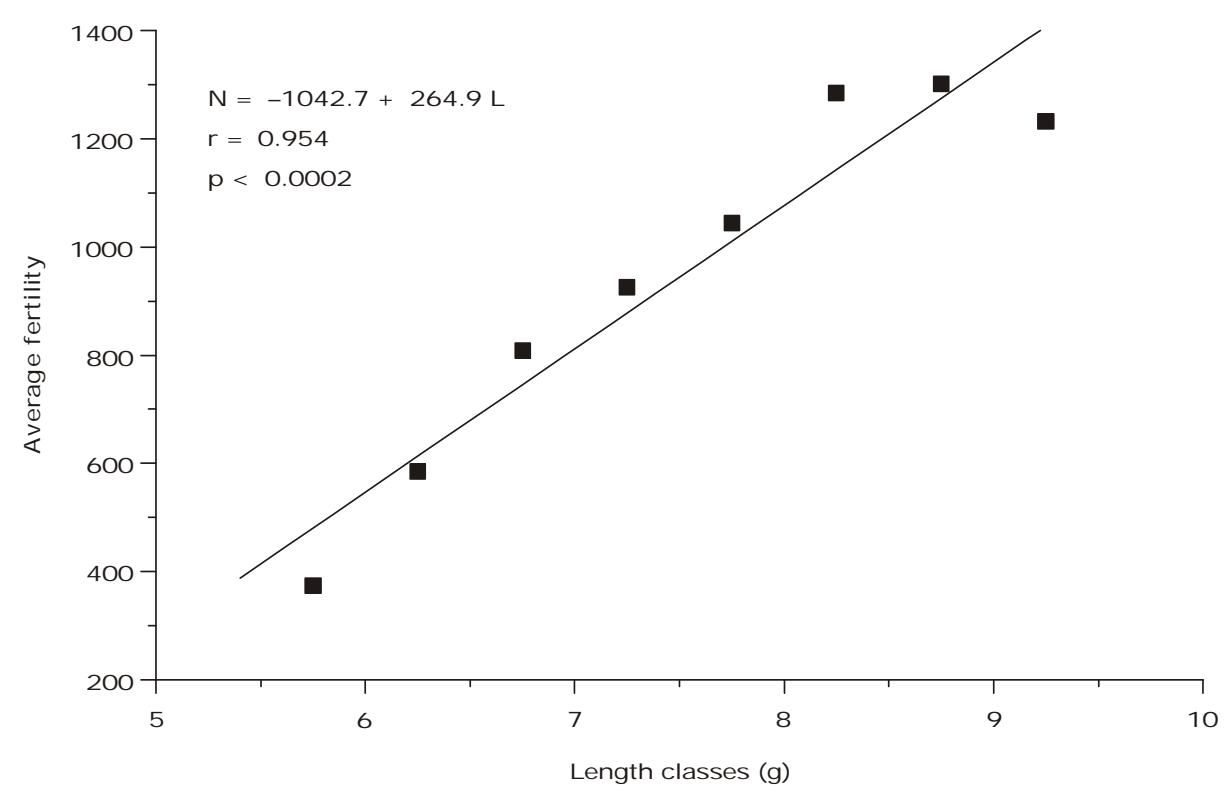

Fig. 5 - Relationship between average fertility (N) and classes length (L) for M. amazonicum females.

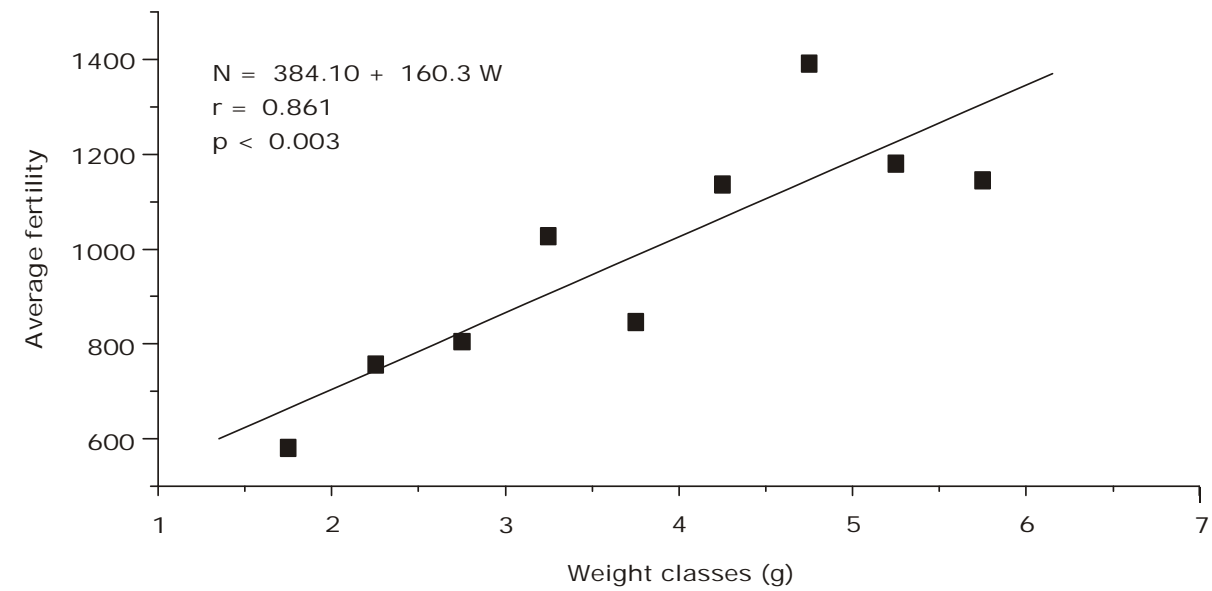

Fig. 6 - Relationship between average fertility (N) and classes weight (W) for M. amazonicum females. 
Maximum fecundity found in this work is close to results reported in literature. According to Lobão et al. (1986), the variations found for fecundity may be attributed to different conditions of female maintenance in the laboratory, female physiological conditions and season, among others. Graziani et al. (1993) explained that in Macrobrachium species the fecundity is extreme associated with the female age, and that it can increase while the female becomes mature.

The fertility of Macrobrachium prawns is very variable too. According to New (1990) the hightest fertility in this genus was observed in $M$. rosenbergii whose mature females can produce 80,000 larvae, while $M$. carcinus, with 70,000 is the second more fertile female. One other native specie, $M$. acanthurus has the fertility lower than the preceding species, Dugan et al. (1975) and Hagood \& Willis (1975), cited by Graziani et al. (1993) observed that a female can hatch 10,000 and 14,500 larvae, respectively.

In this work, the maximum number of larvae observed per hatching for females kept in laboratory was 2,594, higher than the values reported by Guest (1979), Guest \& Durocher (1979), Lobão et al. (1986) and Scaico (1992) who reported 2,200; 565; 1,848 and 1,063 larvae, respectively.

According to Scaico (1992), M. amazonicum has lower fertility compared to other species of commercial value, such as $M$. rosenbergii. This observation is expected, as shown by the $M$. amazonicum fecundity is lower than those others species too. However, as this specie hatchings monthly this fact may compensate for the lower fecundity, thus making commercial culture feasible too.

Based on our results we can deduced that $M$. amazonicum females fecundity and fertility are lower than ones commercial species, nevertheless they can be captured during all year long. The number of captured prawns varied with the level of water in the river, it observe a large number of animals was observed in the months whose level of water was low; the inverse was observed in the months that the river was with a high volume of water.

Acknowledgements - The work was supported by the Conselho Nacional de Desenvolvimento Científico e Tecnológico, CNPq, Brazil and Fundação Cearense de Apoio ao Desenvolvimento Científico e Tecnológico, Ceará, Brazil.

\section{REFERENCES}

ALVES, M. I. M., 1986, Alimentação de Macrobrachium amazonicum (Heller) em condições de laboratório. Ciên. Agron., 17(2): 19-23.

AMARAL, A. M. P. \& NEVES, E. M. A., 1989, Análise econômica da produção de pós-larvas de camarão de água doce. In: Anais do III Simpósio Brasileiro sobre Cultivo de Camarão, 15-20 de outubro de 1989, João Pessoa, Vol. 2: Camarão de Água Doce e Outros. (Ed. by M. M. M. Martins, E. S. Correia \& J. M. Cavalheiro), pp. 429-437. MCR Aquacultura, João Pessoa.

ATLAS DO CEARÁ, 1995, Iplance, Fortaleza, 64p.

BIALETZKI, A., NAKATANI, K., BAUMGARTNER, G. \& BOND-BUCKUP, G., 1997, Occurrence of Macrobrachium amazonicum (Heller, 1862) (Decapoda, Palaemonidae) in Leopoldo's inlet (Resacado do Leopoldo), upper Paraná river, Porto Rico, Paraná, Brasil. Rev. Brasil. Zool., 14(2), 379 390 .

BOND, G. \& BUCKUP, L., 1982, O ciclo reprodutor de Macrobrachium borellii (Nobili, 1896) e M. potiuna (Müller, 1880) (Crustacea, Decapoda, Palaemonidae) e suas relações com a temperatura. Rev. Brasil. Biol., 42(3): 473-483.

BOWMAN, T. E. \& ABELE, L. G., 1982, Classification of the recent crustacea. In: L. G. Abele (ed.), The biology of crustacea: systematics, the fossil record and biogeography. New York Acad. Press Inc., New York, v. 1, pp. 1-27.

CAVALCANTI, L. B., 1998, Histórico. In: W. C. Valenti (ed.), Carcinicultura de água doce: tecnologia para produção de camarões. FAPESP, São Paulo. IBAMA, Brasília, pp. 21-46.

CHACE, F. A., 1992, On the classification of the Caridea (Decapoda). Crustaceana, 63(1): 70-80

COELHO, P. A., RAMOS-PORTO, M. A. \& SOARES, C. M. A., 1981, Cultivo de camarão do gênero Macrobrachium Bate (Decapoda, Palaemonidae) no Brasil. Emparn, Natal, 6: 66 .

COELHO, P. A., RAMOS-PORTO, M. \& SOARES, C. M. A., 1982a, Biologia e cultivo de camarão de água doce. Série Aquacultura, 1, Centro de Tecnologia do Depto. de Oceanografia, Universidade Federal de Pernambuco, 53p.

COELHO, P. A., RAMOS-PORTO, M., BARRETO, A. V. \& COSTA, V. E., 1982b, Crescimento em viveiro de cultivo do camarão canela Macrobrachium amazonicum (Decapoda, Palaemonidae). Rev. Brasil. Zool., 1(1): 45-49.

GAMBA, A. L., 1984, Different egg-associated and larvae development characteristics of Macrobrachium jelskii and Macrobrachium amazonicum (Arthropoda: Crustacea) in a Venezuelan continental lagoon. Intern. J. Invert. Reprod. Develop., 7: 135-142.

GOMES-CORRÊA, M. M., 1977, Palemonideos do Brasil (Crustacea-Decapoda-Natantia). Dissertação de Mestrado em Zoologia, Universidade Federal do Rio de Janeiro, Brasil, $191 \mathrm{p}$. 
GRAZIANI, C. A., CHUNG, K. S. \& DONATO, M., 1993, Comportamiento reproductivo y fertilidad de Macrobrachium carcinus (Decapoda: Palaemonidae) en Venezuela. Rev. Biol. Trop., 41(3): 657-665.

GUEST, W. C., 1979, Laboratory life history of the palaemonid shrimp Macrobrachium amazonicum (Heller) (Decapoda, Palaemonidae). Crustaceana, 37(2): 141-152.

GUEST, W. C. \& DUROCHER, P. P., 1979, Palaemonid shrimp Macrobrachium amazonicum: effect of salinity and temperature on survival. Prog. Fish-Cult., 41: 14-18.

HOLTHUIS, L. B., 1952, A general revision of the Palemonidae (Crustacea, Decapoda, Natantia) of the Americas. Allan Hancock Foundation Publications, Occasional Papers, v. $12,396 \mathrm{p}$.

HOLTHUIS, L. B., 1980, FAO species catalogue. Shrimps and prawns of the world. An annotated catalogue of species of interest to fisheries. FAO Fish. Synopses, 125(1): 261.

ISMAEL, D. \& NEW, M. B., 2000, Biology. In: M. B. New, W. C. Valenti (eds.), Freshwater prawn culture. Blackwell, Oxford, pp. 18-40.

JALIHAL, D. R., SANKOLL, K. N. \& SHENOY, S., 1993, Evolution of larvael developmental patters and the process of freshwaterization in the prawn genus Macrobrachium Bate, 1868 (Decapoda, Palaemonidae). Crustaceana, 65(3): 365-376.

KENSLEY, B. \& WALKER, I., 1982, Palaemonid shrimps from the Amazon Basin, Brasil (Crustacea, Decapoda, Natantia). Smith. Contrib. Zool., 362: 1-28.

KUTTY, M. N., HERMAN, F. \& LE MENN, H., 2000, Culture of other prawn species. In: M. B. New \& W. C. Valenti (eds.), Freshwater prawn culture. Blackwell, Oxford, pp. 393-410.

LOBÃO, V. L. \& ROJAS, N. E. T., 1991, Camarões de água doce: da coleta ao cultivo, à comercialização. Ícone, São Paulo, 112p.

LOBÃO, V. L., ROJAS, N. E. \& VALENTI, W. C., 1986, Fecundidade e fertilidade de Macrobrachium amazonicum (Heller, 1862) (Crustacea, Decapoda) em laboratório. Bol. Inst. Pesca, 13(2): 15-20.

LOBÃO, V. L., VALENTI, W. C. \& MELLO, J. T. C., 1985, Fecundidade em Macrobrachium carcinus (L.) do Rio Ribeira de Iguape. Bol. Inst. Pesca, 12(3): 1-8.

LOMBARDI, J. C., LOBÃO, V. L. \& ROVERSO, E. A., 1996, Estudos populacionais de Macrobrachium birai Lobão, Melo e Fernandes e Macrobrachium petronioi Melo, Lobão e Fernandes das regiões de Cananéia e Juréia (SP-Brasil): II. Dinâmica do crescimento. Bol. Inst. Pesca, 23: 47-54.

MAGALHÃES, C., 1985, Desenvolvimento larvael obtido em laboratório de palemonídeos da região amazônica. I. Macrobrachium amazonicum (Heller, 1862) (Crustacea, Decapoda). Amazoniana, 9(2): 247-274.

MAGALHÃES, C., 1988, The larvael development of Palaemmonid shrimps from the Amazon region reared in the laboratory. II. Extremely abbrevieted larvael development in Euryrhynchus Miers, 1877 (Decapoda, Euryrhynchunae). Crustaceana, 55(1): 39-52.
MAGALHÃES, C. \& WALKER, I., 1988, Larvael development and ecological distribution of central amazonian Palaemonid shrimps (Decapoda, Caridea). Crustaceana, 55(3): 279-292.

MORAES-RIODADES, P. M. C. \& VALENTI, W. C., 2001, Freshwater prawn farming in Brazilian Amazonian shows potential for economic and social development. Global Aquaculture Advocade, 4(4): 73-74.

MOREIRA, G. S. \& McNAMARA, J. C., 1986, The effect of salinity on the upper thermal limits of survival and metamorphosis during larvael development in Macrobrachium amazonicum (Heller) (Decapoda, Palaemonidae). Crustaceana, 50(3): 231-238.

NEW, M. B., 1990, Freshwater prawn culture: a review. Aquaculture, 88: 99-143.

NEW, M. B., 1995, Status of freshwater prawn farming: a review. Aquac. Res., 26: 1-54.

NEW, M. B., 2000, History and global status of freshwater prawn farming. In: M. B. New \& W. C. Valenti (eds.), Freshwate prawn culture. Blackwell, Oxford, pp. 1-11.

ODINETZ-COLLART, O., 1987, La pêche crevettière de Macrobrachium amazonicum (Palaemonidae) dans le Bas Tocantins, après la fermature du barrage de Tucurui (Brésil). Rev. Hydrobiol. Trop., 20(2): 131-144.

ODINETZ-COLLART, O., 1991a, Strategie de reproduction de Macrobrachium amazonicum en Amazonie Centrale (Decapoda, Caridea, Palaemonidae). Crustaceana, 61(2): 253-270

ODINETZ-COLLART, O., 1991b, The Tucurui dam and the populations of the prawn Macrobrachium amazonicum in the Lower Tocantins (PA-Brazil): a four year study. Hidrobiology, 122(2): 213-227.

ODINETZ-COLLART, O. \& MAGALHÃES, C., 1994, Ecological constraints and life history of palaemonid prawns in Amazonia. Verh. Internat. Verein. Limnol., 25: 2460-2467.

ODINETZ-COLLART, O. \& RABELO, H., 1996, Variation in egg size of the fresh-water prawn Macrobrachium amazonicum (Decapoda: Palaemonidae). Journal of Crustacean Biology, 16(4): 684-688.

PAIVA, M. P. \& CAMPOS, E., 1995, Fauna do Nordeste do Brasil: conhecimento científico e popular. Banco do Nordeste do Brasil, Fortaleza, 273p.

PINHEIRO, M. A. A. \& HEBLING, N. J., 1998, Biologia de Macrobrachium amazonicum (De Man, 1879). In: W. C. Valenti (ed.), Carcinicultura de água doce: tecnologia para produção de camarões. FAPESP, São Paulo. IBAMA, Brasília, pp. 21-46.

PINTO, E. M., 1977, O camarão canela, Macrobrachium amazonicum (Heller), em açudes públicos do Nordeste do Brasil administrados pelo Departamento Nacional de Obras contra as Secas. Monografia de Graduação, Universidade Federal do Ceará, 43p.

PORTO, L. A. C., 1998, Estrutura populacional e biologia reprodutiva de Macrobrachium amazonicum (Heller, 1862) (Crustacea, Decapoda, Palaemonidae) na bacia hidrográfica do Rio Meia Ponte, Bela Vista de Goiás-GO, Brasil. Tese de Doutorado em Oceanografia Biológica, Universidade de São Paulo, Brasil, 117p. 
RODRIGUEZ, G., 1980, Los crustaceos decapodos de Venezuela. Instituto Venezolano de Investigaciones Científicas, Caracas, $443 \mathrm{p}$

ROMERO, M. E., 1980, Preliminary observations on potential of culture of Macrobrachium amazonicum in Venezuela. In: M. B. New (ed.), Giant prawn farming. Elsevier, Amsterdam, pp. 411-416.

SANTOS, E. P., 1978, Dinâmica de populações aplicada à piscicultura. Hucitec/Edusp, São Paulo, 130p.

SCAICO, M. A., 1992, Fecundidade e fertilidade de Macrobrachium amazonicum (Crustacea, Decapoda) de um açude do Nordeste brasileiro. Bol. Inst. Pesca, 19: 89-96.

SCAICO, M. A. \& BRAGAGNOLI, G., 1989, Influência da salinidade na sobrevivência dos adultos e dos primeiros estágios larvaeis do camarão de água doce Macrobrachium amazonicum (Heller, 1862). In: M. M. M. Martins, E. S. Correia \& J. M. Cavalheiro (eds.), Anais do III Simpósio Brasileiro sobre Cultivo de Camarão, 15-20 de outubro de 1989, João Pessoa, Vol. 2: Camarão de Água Doce e Outros. MCR Aquacultura, João Pessoa, pp. 339-351.

SILVA, J. W. B., SANTOS, E. P. \& MELLO, J. T. C., 1982, Curva de rendimento do camarão, Macrobrachium sp (Decapoda Palaemonidae), do açude público Cedro (Quixadá, Ceará, Brasil). Ciência e Cultura, 34(7): 915-917.

VALENTI, W. C., 1985, Cultivo de camarões de água doce. Nobel, São Paulo, 82p.

VALENTI, W. C., 1990, Criação de camarões de água doce Macrobrachium rosenbergii. In: Reunião Anual da Sociedade Brasileira de Zootecnia, 27, Reunião da Associação Latino-Americana de Produção Animal, 12, Campinas. Anais... pp. 757-785.

VALENTI, W. C., 1993, Freshwater prawn culture in Brazil. World Aquacult., 24(1): 30-34.
VALENTI, W. C., 1996, Criação de camarões em águas interiores. Boletim Técnico do Centro de Aqüicultura da Universidade Estadual Paulista 2, Fundação de Estudos e Pesquisas em Agronomia, Medicina Veterinária e Zootecnia, Jaboticabal, 81p.

VALENTI, W. C., 2002, Situação atual, perspectivas e novas tecnologias para produção de camarões de água. In: Anais do XII Simpósio Brasileiro de Aqüicultura, junho de 2002, Goiânia, pp. 90-106.

VALENTI, W. C., MELLO, J. T. C. \& LOBÃO, V. L., 1986, Dinâmica da reprodução de Macrobrachium acanthurus (Wiegmann, 1836) e Macrobrachium carcinus (Linnaeus, 1758) do rio Ribeira do Iguape (Crustacea, Decapoda, Palaemonidae). Ciência e Cultura, 38(7): 1256-1262.

VALENTI, W. C., MELLO, J. T. C. \& LOBÃO, V. L., 1989, Fecundidade em Macrobrachium acanthurus (Wiegmann, 1836) do Rio Ribeira do Iguape (Crustacea, Decapoda, Palaemonidae). Rev. Bras. Zool., 6: 9-15.

VAZZOLER, A. E. A., 1982, Manual de métodos para estudos biológicos de populações de peixes: reprodução $e$ crescimento. CNPq, Programa Nacional de Zoologia, Brasília, $108 \mathrm{p}$.

VEGA-PEREZ, L. A., 1984, Desenvolvimento larval de Macrobrachium heterochirus (Wiegmann, 1836), Macrobrachium amazonicum (Heller, 1862) e Macrobrachium brasiliense (Heller, 1862) (Crustacea, Decapoda, Palaemonidae) em laboratório. Tese de Doutorado em Oceanografia Biológica, Universidade de São Paulo, Brasil, 277p.

WILLIAMS, A. B., 1984, Shrimps, lobsters and crabs of the Atlantic coast on the Eastern United State, Maine to Florida. Smithsonian Institution Press, Washington, 550p. 